\title{
Budapest Butchers, the Jewish Question, and Holocaust Survivors
}

\section{István Pál Ádám}

Central European University IAS / A Selma Stern Zentrum, Claims Conference Saul Kagan

Fellow in Advanced Shoah Studies

Adami@ceu.edu

This article focuses on a denazification procedure within the professional group of the Budapest butchers. Through the retelling of wartime anti-Jewish incidents and other conflicts, these processes reveal a complex picture of how a certain professional group tried to cope with the upheavals of the war and the attempts of outside interventions. In the framework of the anti-Jewish exclusionary atmosphere of the epoch, I investigate questions about professional competition, leadership, respectability, professionalization, and the marginalization of Jewish professionals. By answering these questions, I reconstruct a wartime internal dynamism within the butchers' trade, where meat gradually became a scarcity, and therefore ousting Jewish colleagues was understood more and more as an urging necessity. In these circumstances, I am interested in the ways of solidarity and animosity showed by the Budapest butchers towards persecuted colleagues and towards Jews in general. By using a micro-historical method, I detail the professional problems of Budapest butchers, and I explain how the denazification check interestingly took over some functions of the "master's exam," after the Second World War.

Keywords: Transitional justice, occupational groups and the Holocaust, denazification, respectability, microhistory of Holocaust, individual help during the Holocaust, food ration, Jews and Gentiles during the Holocaust

This paper explores the ways in which Jewish origins and political affiliation mattered during the Second World War in an urban setting if one happened to work as a butcher, or when meat was needed as foodstuff. Among Budapest butchers, as in most of the professional clusters in Hungary, Jewish and leftist colleagues found themselves marginalized starting from 1939. Butchers were not unique in this sense, yet this professional group may have been particularly important simply due to the scarcity of meat in the later phase of the war, which mixed this ideological side-lining with a bitter fight against professional competition.

Considering the bigger picture, the marginalization of Jewish professionals and political opponents was, of course, a phenomenon that could be observed in several Central European countries. Jews in Germany were segregated from the rest of the urban communities in which they lived years earlier than in 
Budapest. Nevertheless, just like in Hungary, in 1945, "the collapse of the Third Reich reversed social hierarchies, with former Nazis losing their privileges and their erstwhile victims having the power to decide on their fates." ${ }^{1}$ In a similar vein, following the war in the Hungarian capital, in spring 1945, some of the previously marginalized butchers came back and staged an anti-Nazi purge in this occupational cluster.

A key tool in taking vengeance was the immediate post-war denazification process which was organized as part of a larger screening of Hungarian public life. This obligation followed from the truce agreement Hungary had signed with the victorious Allied powers at the end of the Second World War, and it aimed at a sort of spiritual and ethical turn in public life. ${ }^{2}$ Organized by the professional chambers and trade unions, beginning in the spring of 1945, a denazifying check took place which was based in no small part on the wartime behaviour of individuals working in specific trades and professions. The members of the justificatory committees included labour union officials, legal experts, and the delegates of the democratic political parties of the so-called Hungarian National Independence Front, a Soviet backed umbrella organization of the anti-Fascist political powers. ${ }^{3}$

On the following pages, I am going to analyse the documentation of the transitional justice procedures recorded by the justificatory committee of the Budapest Butchers' and Slaughtermen's Chamber, and I am going to complement my findings with discussion of the wartime primary sources. By analysing the minutes of the meetings of this justificatory committee and the declarations which were submitted, I am able to reconstruct microhistories of the Holocaust on the basis of immediate post-war sources. While doing this, I want to ask questions about (1) the non-Jewish individuals' wartime choices, including whether or not they sought to benefit from the anti-Jewish regulations?; and (2) whether the butchers of Budapest had any chance to provide help for Jews?; also (3) in what ways and from when did one's Jewish origin matter in an everyday trade such as meat selling and processing?; and, finally, (4) how did

1 Jarausch, Broken Lives, 238.

2 This truce agreement was signed in Moscow on 20 January 1945. See Barna and Petô, Political Justice in Budapest, 14.

3 The Magyar Nemzeti Függetlenségi Front [Hungarian National Independence Front] was formed on 2 December, 1944 in Szeged, south-east Hungary. It was founded by the following political parties: the Independent Smallholders Party, the Hungarian Communist Party, the Social Democratic Party, the National Peasant Party, and the Civic Democratic Party [Független Kisgazdapárt, Magyar Kommunista Párt, Szociáldemokrata Párt, Nemzeti Parasztpárt and Polgári Demokrata Párt]. 
market control and internal group cohesion evolve during the Second World War among the Budapest butchers?

\section{Persilschein, George Mosse, and the Budapest Butchers}

Writing about the immediate German post-war situation, Konrad H. Jarausch describes the 1945 phenomenon of Persilschein, alluding to the papers issued by the few German Jewish survivors of the Holocaust, who were continuously nudged by German petitioners "to provide an affidavit, called Persilschein after a laundry detergent, that would prove their [the German petitioners'] innocence." 4 Files left behind by the justificatory committee of the Budapest Butchers' and Slaughtermen' Chamber provide proof that this piece of paper often featured in transitional justice processes in other countries as well, which not long before had belonged to the Axis alliance. Nevertheless, while in Germany possessing a Persilschein often put an end to any further investigation, in the Hungarian context, denazification was sometimes taken more seriously. ${ }^{5}$

The denazification related archival material of the Budapest butchers' professional chamber contains various other types of documents. This makes it easier for the researcher to differentiate between people who actually provided help and those wrongdoers who only arranged similar supporting statements to avoid post-war retribution. Most typically, numerous butchers got into trouble after the war because they had been taking steps to deny their Jewish colleagues' access to meat during the war. On 10 May, 1942, the deputy leader of the meat industry workers' association delivered a speech at this organization's assembly. Speaking about the problems faced by this professional group, he offered his opinion concerning the Jewish colleagues, whose effective exclusion from the pork- and veal market had brought the unwanted result of Jewish dominance in beef commerce. ${ }^{6}$ One representative of the slaughterhouse workers, Mr. Dancs, suggested ousting the Jews also from the beef market.

The issue was addressed in a short while, when still in 1942, a nine-member committee was set up at the cow slaughterhouse, the members of which

4 Jarausch, Broken Lives, 266.

5 Dan Stone claims that, in general, the Allied occupiers of Germany did not want to criminalize the German masses because of their concerns over future Western European security. Yet with regards to the process of denazification, there were differences, since it was "far more energetically pursued in the American zone than in the French or British..." Stone, Goodbye to all that?, 54-55.

6 See Ferenc Bukovszky deputy president's speech in the periodical of the Hungarian Meat Industry Workers [Magyar Husiparosok Lapja], 15 May, 1942, vol. 4, no. 21, 1-3. 
monopolized the distribution of live animals arriving through their contact with MÁSZ, the state agency for selling and buying animals. ${ }^{7}$ Contemporaries saw the role of MÁSZ as making sure that Christianity as a cultural trait prevailed even at the slaughterhouses. ${ }^{8}$ Run by state officials, it tendentiously preferred members of extreme right organizations when it came to distributing the best-looking animals for slaughtering, which is why, for example, Árpád Horváth slaughterman had joined the National Socialist party in the early 1940s.

Historian George L. Mosse reminds us that "we must understand the actions and commitments of people as they themselves saw them and not project ourselves back into history." Mosse, who himself had to escape from the Nazis in 1933, suggests that on the one hand, "a historian in order to understand the past has to empathize with it, to get under its skin, as it were, to see the world through the eyes of its actors and its institutions," ${ }^{10}$ while, on the other hand, he claims that "understanding does not mean withholding judgement $[\ldots]$ but understanding must precede an informed and effective judgement." ${ }^{11}$ Keeping this in mind, it is worth mentioning that although butcher Árpád Horváth had become a member of the National Socialist party only to get access to meat, he cancelled his membership once this party united with the Arrow Cross Party, a move after which he did not receive proper meat for a longer period of time. His case should be evaluated differently than those of his colleagues who remained Arrow Cross Party members even in autumn 1944 (some of whom will be mentioned later), when it was already evident that the party had become a driving force behind the campaign waged against Jewish Hungarians.

Nonetheless, back in 1942, there were more sophisticated ways of eliminating Jewish competition from the meat market other than simply checking one's political affiliation. Selling fresh beef was the job of Dezső Szamek at the cow slaughterhouse, where on 1 May, 1942, he was offered more than the official maximum price for half of a freshly slaughtered cow. By then, the authorities

7 The abbreviation stands for Magyar Állat és Állati Termékek Kiviteli S zövetkezete.

8 As one reminiscent recalled, "the role of MÁSZ was to make sure the Christian idea prevailed in the slaughterhouse" [In the original it reads: "A MÁSZ-nak az volt a szerepe, hogy az ún keresztény gondolatot juttassa érvényre a vágóhídon.” HU BFL XVII. 1597, box no 1., A Budapesti Mészárosok és Hentesek Ipartestületének Igazolóbizottsága Iratai [Documents of the justificatory committee of the Budapest Butchers and Slaughtermen], the case of Brzezanszky. Hereafter I reference this material merely by the archival number HU BFL XVII. 1597.

9 Mosse, Confronting History, 108.

10 Ibid., 53.

11 Ibid., 172. 
had realized that the circumstances of total war, the limited availability of livestock, and the almost unlimited needs of the army required much more control over meat products than what a peacetime market mechanism could provide. Therefore, they introduced a cap on the number of animals selected for slaughtering and put another cap on the prices as well. ${ }^{12}$ In this specific case, butcher Dezső Szamek, who was of Jewish descent, had been offered a higher price than this set maximum, and he did not realize the catch in the situation. Once he accepted the offer, he was almost immediately arrested by policemen and was held behind bars for approximately a year because of his carelessness. ${ }^{13}$

His was not a unique case, as several unwanted Jewish or leftist butchers were eliminated with the use of similar tricks. Obviously, they lost not only their licenses to work but were also subjected to severe fines. Somewhat more general and much more violent actions against Jewish butchers happened only sporadically, when for example the meat bought by Jewish retailers was simply confiscated at the slaughterhouse by radical extremist butchers from the Garay market hall. ${ }^{14}$ Witnesses claimed that Károly Dancs belonged to the leaders of the radicals, who had by force attempted to put their Jewish colleagues into an untenable situation as early as $1942-43 .^{15}$

\section{Discussions among the Budapest Butchers and Their Anachronistic Apprentice System}

Placing these anti-Jewish incidents into the internal discussions held among the members of the meat industry, I could identify three major themes that occupied the thoughts of these people in wartime Budapest. Quite clearly, the above mentioned anti-Semitic acts belonged to those topics which evolved around the so-called Jewish question, but there was equally a lot told about the distribution

12 It was decree no. 2760/1941 of the Ministry of Public Supply [Közellátásügyi Minisztérium] in April 1941 that announced the maximum number of animals for slaughter per settlement. It also named the MÁSZ as the authority that was responsible to supply the Hungarian capital with meat.

13 HU BFL XVII. 1597, Find this in the case of Flórián Gyurasits, within this case see especially the statements of Mr. Kapay, recorded on 6 October, 1945.

14 The confiscation is mentioned, for example, in the discussion of József Bors's case (BFL XVII 1597, box no. 1), on 1 October, 1945, but also in the case of Sándor Varga, BFL XVII 1597, box no. 6.

15 Sándor Varga claimed that he could not speak up against the violent confiscation of meat because of Dancs's aggressive, commanding style. See on this BFL XVII 1597, box no. 6, an appeal from Sándor Varga to the People's Court, arrived on 12 June, 1945. A certain László Tóth, a member of the Arrow Cross Party allegedly also belonged to this violent group. See his case at BFL XVII 1597, box no. 5, and within his file a document numbered 3221/1945. 
of meat between the butchers and, finally, the members often discussed issues related to the apprentice-system as well. Understanding the butchers' individual decision-making processes would be a difficult task without dwelling a bit around these three themes.

Starting at the end, the apprentice-system was chiefly about the next generations of butchers, but it was also connected to the existing businesses. Professions such as butchering had traditions which stretched back to the late medieval guild system, where a member of a guild would train a young apprentice who worked for him for years. Small modifications were often made to this traditional on-the-job-training system, but it remained fundamentally unchanged for centuries. One of the features which did not change was that it demanded enormous sacrifices, especially from the apprentice.

Typically, one would enter apprenticeship at a well-established butcher's around the age of 14 and stay there for some three to four years, working almost as an in-house servant. Only after this challenging three-year-long learning process had been completed would the apprentice become an assistant butcher. This stage in a career usually lasted many years in order to give the assistant butcher the chance to gain experience and the savings necessary to open his own butcher shop. Nevertheless, before an assistant butcher could officially become a member of the professional group of butchers, he had to take the "master's exam," an examination with which the professional group could also control the number of incoming competitors. Take the example of András Krizsán, who was born in 1865. At the age of fourteen, young Krizsán became a butcher apprentice in 1879, and he remained in this position for three years. ${ }^{16}$ As a next step, he was then promoted to assistant butcher, a position he held for no less than eight years, and only in 1890 was he able to pass the master's exam for butchers and subsequently open his own shop. Thus, it took Mr. Krizsán some eleven hard years to become an independent butcher.

Understandably, the young men of interwar Budapest were able to find much easier career options than this. In this growing metropolis, even unqualified factory workers could sometimes count on immediate sizeable incomes and they could also retreat for paid holidays. Butchers were not always able to compete with the salaries and benefits offered by manufacturers, public transport companies,

16 See Mr. Krizsán's obituary published in the periodical of the Hungarian Meat Industry Workers [Magyar Husiparsok Lapja], 26 March, 1943, vol. 5, no. 13, 3. 
or the growing Budapest nightlife to young workforce. ${ }^{17}$ In addition, opening a new butcher shop required a substantial investment. At the same time, modern industrial developments created a need for fast and specialized workforces, meaning that the tradition of passing all the knowledge about a specific profession became increasingly difficult from one generation to the next one.

Nevertheless, the butchers of Budapest organized master's exams every year, and they even held these exams in 1943-44, simply because this exam had a crucial double function. On the one hand, it separated competent from incompetent, on the other hand, it provided an entry control to the profession for the association of Budapest butchers. The further downfalls of the apprentice system in the modern era is a subject that remains outside of the focus of the present paper. It was an issue which caused problems in the professional cluster under discussion, nevertheless, in the next section of this essay, I am rather going to turn my attention to the details of the remaining two themes of the Budapest butchers' frequent discussions, namely the anomalies of meat distribution and its interplay with the so-called "Jewish question."

\section{Meat Distribution and the "Jewish Question"}

When in 1941, the Hungarian government placed restrictions on the purchase and sale of meat products, the decision was made to tie meat distribution to the size of businesses within the meat industry. In theory, the authorities wanted to protect employees this way. In practice, this meant that the amount of meat a butcher could get at the slaughterhouse depended on the number of assistant butchers and apprentices he was employing, and the number of shops he was running. However, the quality of the meat was no less important than the quantity, therefore connections and political affiliation greatly mattered at the slaughterhouse, and it appears that those distributing the meat happened to be almost exclusively the followers of right-wing Hungarian nationalism. Butchers whom they disliked were doomed to wait until the end of the day, when highquality meat was no longer available and even low-quality meat was not available in adequate quantities. At least this is how Konrád Fischer recalled the situation. He was a butcher who had regularly stood in line from early morning until late

17 The periodical of the Hungarian Meat Industry Workers blames explicitly the technical and industrial expansion that damaged in general the interests of artisans. "A tanonckínálat fokozása," Magyar Husiparosok Lapja, 1943, vol 5, no. 22, 1. 
evening for some 50 or 60 kilograms of meat. ${ }^{18}$ Those who had better access to fresh meat and better treatment from the slaughtermen were members of the right-wing organizations and representatives of big companies.

Following the war, Mihály Fejes from Visegrádi utca, in a letter dated 5 March, 1945 and sent to the denazification committee, tried to explain his membership in the Arrow Cross Party, which he had joined in $1942 .{ }^{19}$ His explanation included wartime threats, according to which, had he refused to join the Arrow Cross, he would have gotten less and less meat, which outcome could have led to the closure of his shop. Mr. Fejes attached a Persilschein signed by one of his Jewish Hungarian customers declaring that he had always sold him meat (even in 1944) and he had also sent some food for the customer to a Yellow star ghetto house. ${ }^{20}$ It is noteworthy that Mr. Fejes submitted these documents in 1945 from an internment camp which was a regular post-war destination for people who had been accused of having been members of the Arrow Cross party. It is also revealing that in the spring and summer of 1945, this kind of wartime affiliation was enough for someone to lose his or her job and his or her freedom for some time.

However, less than two years after the war, when the People's Court had to reach a decision in a similar case where the condemned butcher had appealed against the verdict reached by the immediate post-war denazification committee, the evaluation process was much more lenient. This difference had something to do with the impending leftist switch in Hungarian public and political life. To get a sense of this, one needs merely read the arguments used by the judges in the case of Károly Dancs, who was mentioned earlier and who had been accused of robbing the Jewish butchers of their meat in 1942 at the slaughterhouse. For this misconduct in August 1945, the justificatory committee banned him for life from working in the meat industry, while the People's Court changed this ruling and reduced the term of the ban to one year. In its verdict issued on 20 September, 1946, the People's Court maintained that butcher Dancs had only joined the Arrow Cross party because of the pressing economic circumstances, which were a consequence of the war. According to the judges, Dancs's anti-

18 HU BFL XVII. 1597, See the appeal of Konrád Fischer addressed to the People's Court on 2 October, 1945.

19 HU BFL XVII. 1597, See the case of Mr Fejes discussed by the Justificatory committee on 15 May, 1945.

20 HU BFL XVII. 1597, See this in the Fejes case, and within that the statements signed by Ferenc Kuzért and Lipót Mandel. 
Jewish actions were caused by the misleading extreme-right propaganda, which as a simple worker, he had been unable to resist. Furthermore, in any case, his actions allegedly had originated primarily from a just social class struggle against the big businesses, and these actions only had a secondary anti-Jewish character. ${ }^{21}$ This reasoning illustrates how, paradoxically, wartime anti-Jewish sentiment was at times transformed into a post-war antisemitism. In these instances, even in a denazifying procedure, the leftist anti-capitalist propaganda could create a common platform between former Nazis and new leftist candidates for power.

True, being a butcher in Budapest became an increasingly difficult profession during Second World War due to the lack of food stuff, however, the situation had not been much easier in the pre-war years. Already in 1936, there were no less than 920 individual entrepreneurs in this trade in the city, and they had to compete not only with one another, including the bigger companies, but also with the state-run food selling chain. This enterprise, the Községi Élelmiszerüzem, inevitably had advantages in accessing foodstuff and setting its prices, as it did not have to bring in much profit. ${ }^{22}$ The situation was manageable as long as the government did not start to restrict the butchering of animals due to the war. Once there was not enough meat, it became obvious that the shrinking supply could not keep all the individual butcher shops of Budapest profitable.

The fact that there was not an adequate supply of meat to provide an income for all the members of this industry puts the anti-Jewish acts described above into perspective: they were part of the broader debate which could be formulated vaguely as "whom should be eliminated from the Budapest butchers in order to secure the survival of the rest of the businesses?" And one growingly popular answer to this question was the word "Jews." To be sure, the so-called "change of the guards" [in Hungarian Örségváltás] notion, i.e. the Christian takeover of Jewish positions in economy, was widely present among large segments of Hungarian society. ${ }^{23}$ The first anti-Jewish regulations were popular among the gentile population, and these measures resulted in significant gains for the proNazi Arrow Cross movement in the parliamentary elections of 1939.

21 HU BFL XVII. 1597, People's Court decision under the number 5094/1945/2, issued on 20 September, 1946.

22 The so-called Községi Élelmiszerüzem [Municipal Food Store Network] was founded in 1911, and to give an idea of its size, in 1937 it had 600 employees and its trading was estimated in the region of 13 million pengős. See on this the speech of Ferenc Vály at the Budapest City Assembly quoted in Magyar Országos Tudósitó, 1937/257. 3.

23 See on the notion of the Change of the guard or, in Hungarian, on Örségváltás most recently Linda Margittai's dissertation: Margittai, Zsidókérdés a Délvidéken. 
In line with this, the periodical Hungarian Meat Industry Workers' Journal (Magyar Husiparosok Lapja) regularly pointed out, for example, the Hungarian settlements where no Christian butcher shops were available, suggesting by this not just career options in the provinces but also that there was a need to counter the alleged "Jewish influence." Yet, for the purpose of this paper, it is much more crucial to point at the Christian and rightist preferences that were practiced on a daily basis at the slaughterhouses in the Hungarian capital. Knowing this, the wealthy Zeidl butcher company, for instance, always sent an employee who had an affiliation with the Arrow Cross to do the wholesale shopping. ${ }^{24}$

According to people's recollections after the war, several similar buyers had worn the Arrow Cross badge, and names were even mentioned of meat distributors who had been known for giving better quality products to those who had openly supported the Arrow Cross leader Szálasi and, in general, the Nazi German war efforts. ${ }^{25}$ Slaughterman István Varga declared that Jewish butchers should not even try to buy meat at the slaughterhouse, but rather should go to Palestine. ${ }^{26}$ Another slaughterhouse worker, Mr. Somody, reportedly wore both the green shirt of the Arrow Cross uniform and the movement's badge every day. ${ }^{27}$ The Kozma brothers had been producing various types of meat products for years, however, in 1942, realizing that due to their Jewish background they had hardly any access to fresh meat, they decided to lease their workshop and shop in Rökk Szilárd utca. Two years later, when the lease contract was about to expire and the Jewish owners did not intend to prolong it, the nonJewish butcher threatened to hand them over to the Nazi Germans, who in the meantime had occupied the country. ${ }^{28}$ Those affected also remembered that soon after the original business takeover in 1942, photos of Hitler and Mussolini were displayed in the shop window.

And these pictures lead us to the issue of the choices made by customer, as in its practical way, these choices can be understood as expressions of opinion within the debate on the Jewish question. It should be stated that in wartime Budapest,

24 HU BFL XVII. 1597. See the case of István Zeidl in box no. 6, especially see the discussions on 29 September, 1945.

25 HU BFL XVII. 1597. Find this in the case of Gyula Kelemen.

26 HU BFL XVII. 1597. The case of István Varga, see the records of the hearing held on 8 December, 1945.

27 HU BFL XVII. 1597. See the case of Árpád Somody in box no. 5.

28 HU BFL XVII. 1597. See the case of András Várszegi/Winkhardt who after the war was arrested because in 1944, he had blackmailed the owners to renew the rental contract. The denazification authority withdrew his license for five years, and banned him from working as a butcher. 
there was clearly a need for trusted extreme right-wing meat sellers first. Only after this need had emerged did the butchers begin listing themselves in selective trade organizations that ensured the seller's political "trustworthiness" for the politically conscious customers. For instance, a case was recorded of a lady from district VI, who stopped shopping for meat at the nearby butcher only because this butcher had not taken her advice and had not joined the Arrow Cross Party or the Alliance "Marok", an organization of the rightist suppliers. ${ }^{29}$ The extreme right "Marok" even published its own yellow pages for right-wing consumers. ${ }^{30}$

Therefore, when attempting to understand the behaviour of butchers, we need to keep in mind the mounting pressure on the macro level, where masses of Hungarians related their nationalist aspirations to a Nazi German-led new world, including in this a racially inferior judgement over their Jewish fellowcitizens. The growing popularity of antisemitism on the macro level was present in the butchers' everyday lives because of the influence of the clientele. Yet on the micro level of the meat industry workers, there was much stronger group pressure, where political belonging mattered the most when butchers needed to do wholesale meat shopping. Through the strong extreme right mentality of the dozens of slaughtermen and butchers working at the slaughterhouses, the community was able to influence the political preferences of the Budapest butchers. This serves as a crucial factor when one attempts to understand how these individuals functioned and made their decisions in the first half of the 1940s. Under these circumstances, it comes as no surprise that onto the window of another butcher shop on Szív utca, in 1942 an announcement was placed with the following text: "Here we do not serve Jews." 31

\section{The Jewish Question and Respectability}

Let us return to the group of Budapest butchers and consider some of the other ways in which the so-called "Jewish question" was understood by them during the Holocaust. The advantage of microhistory is exactly that it "provides more compelling insights into the events that contemporaries faced in their day-to-day lives" and "it gives increased attention to the categories of actors, the strategies of

29 HU BFL XVII. 1598. The files of Justificatory Committee no. 291/a of the Hungarian Concierges and Assistant Concierges, district VII, the case of Mrs. János Hofgart from Barát utca 9, see the hearing of Mr. Jenő Branstadler on 22 August, 1945.

30 See more on this in Markó, "Marok" kereskedók és iparosok szaknévsora.

31 Hadas and Zeke, Egy fölösleges ember élete, 100. 
individuals and small groups." 32 One aspect of the meat industry workers' group strategy in connection to the so-called "Jewish question" was exercised again and again through meat distribution, where those butchers who belonged to the extreme right — those with a dislike towards Jews — had the upper hand. But the "Jewish question" was also raised in the sense of respectability within the group of the Budapest butchers. Generally, respectability is created by social morals, manners, the way someone is expected to behave, look, and represent something or someone. Thus, respectability in short is and was about social acceptance and respect. To draw on the ideas of George L. Mosse again, respectability is the "cement holding society together," and because of the Nazi movements and anti-Jewish laws, during the Second World War, "it had not been considered respectable to be a Jew." ${ }_{3}$ To borrow a term from Erving Goffman, the "social identity" of Jews due to the anti-Jewish campaigns became stigmatized, which appeared to be "deeply discrediting." 34

In this respect, within the micro world of Budapest butchers, we have a prominent example in the person of Mr. Damásdi, who prior to the war had held the deputy leader position within the Budapest meat industry association. Being of Jewish decent, he had been removed from his post in 1939-40, however, after the end of the Second World War, Mr. Damásdi came back and became the president of the very same organization. As president, he oversaw the activity of the justificatory committee entrusted with the denazification of the professions of butcher and slaughterman, and he often reflected on how becoming an outsider at the beginning of the war had hit him. His reflections on this wartime outsiderdom can help us reconstruct when and why being Jewish started to matter among the Budapest butchers.

The first notable event in this process occurred in 1939, when in the Valeria coffee house there was a discussion in the course of which influential butchers like Mr. Schadutz and Ferenc Gábriel expressed their concerns over the leaders of the Budapest butchers' professional chamber. They claimed that their leaders had had their demands rejected by the authorities far too often, allegedly because of the Jewish presence within their leadership. This discussion led to the initiative to "politely ask" Damásdi, who at the time was the deputy head, to leave his

32 Zalc and Bruttmann, Microhistories of the Holocaust, 2-3.

33 Mosse, Confronting History, 180, 211.

34 Goffman, Stigma, 2-3. 
position. ${ }^{35}$ Thus, Mr. Damásdi and other Jewish Hungarians were found unfit to represent the Budapest butchers in public, and, here clearly, being Jewish started to matter in a negative way. This moment was also perceived as an occasion for a change in the elite within the meat industry workers' community on the pretext that Jews could not represent effectively enough a professional trade anymore in a world in which Jewishness is perceived as inferior. Later, when the leadership of the meat workers' chamber was re-elected, the lawyer of the Budapest Butchers' and Slaughtermen's Chamber was not permitted to enter the room where the actual meeting took place because of him being a Jew. He was, however, allowed to keep his position. ${ }^{36}$

It is even more telling that in early 1943, another butcher at the official gathering of the meat industry workers' leaders recommended having the portraits of those colleagues from the "hall of fame" of the Budapest butchers" trade chamber removed, who came from Jewish families. ${ }^{37}$ It is fascinating that the periodical of the meat industry workers found the proposal something worth reporting, but it is even more striking that these Budapest butchers wanted to eliminate the Jews even from the historical memory of their profession by removing these photos from the walls of their chamber's building. Although this proposal still belongs to the realm of social prestige, there is a shift here towards internal stigmatization: since the premises of the Budapest butchers' chamber were used exclusively by the meat industry workers, the question did not concern what the group displayed towards the society. Rather, it was about expressing and reinforcing an already internalized prejudice. Thus, initially, the group's aim was to maintain respectability due to the perceived expectations of outsiders, while these later actions were driven by the already internalized prejudice.

Let us not forget about the tragedy of the members of the Hungarian Second Army who were taking part in the Nazi Garman attack against the Soviet Union. Thousands of these Hungarian soldiers died in the winter of 1942-43 at the Don river bend, while trying to fight the Red Army without proper equipment. Was removing the portraits of Jewish butchers from the wall a reaction to the tragic losses, or did it rather have more to do with the future envisioned by

35 HU BFL XVII. 1597, the case of Ferenc Gábriel box no. 2, see the minutes of the Justificatory Committee dated 5 June 1945.

36 HU BFL XVII. 1597, box no. 1. This lawyer was Miksa Leipnik, who recalled this election during the discussion of Antal Ihász's case in October 1945.

37 This initiative came from Gyula Kádár, and it is mentioned in the periodical of meat industry workers, Magyar Husiparosok Lapja vol. 4, no. 9, 23 February 1943 under the title "Elöljárósági ülésről készült beszámoló" [Report about the meeting of the board]. 
the Budapest butchers? It is difficult to answer these questions, but surely in a more radicalized society with the ongoing war, Jewish butchers were more and more side-lined, and soon the exclusion affected Jewish customers and business partners of the non-Jewish butchers as well.

However, the general situation in the meat industry was also in sharp decline in Budapest. Livestock from the provinces was rarely sent to the Hungarian capital, as farmers could already sell the animals at a high price at nearby locations. This triggered further governmental interventions into the businesses of butchers. By 1 January, 1943, rationing of meat products was introduced in Budapest, where every inhabitant of the city was entitled to just 0.4 kilograms of beef and 0.1 kilograms of pork weekly. Yet, setting these limitations did not solve all the problems..$^{38}$ As a representative of the butchers' chamber phrased it in the city council of Budapest when complaining about the fact that only very poorly fed animals had been sent to the slaughterhouses in the summer of 1943, "certainly enough meat ration cards have been issued, but there is not enough meat available." 39

\section{Some Changes, Options, and Decisions among the Budapest Butchers during the German Occupation and the Reign of the Arrow Cross Party}

For Jewish Hungarians, the situation worsened the most radically with the Nazi German occupation of Hungary in March 1944. Soon after this, Regent Horthy appointed Döme Sztójay as the new prime minister, and from April the same year, Jewish Hungarian individuals were marked with a yellow star badge on their clothes. On 22 April, the government issued new regulations on the supply of Jews, which effectively excluded Jews from meat consumption: order 108.500 K.M. reduced their meat ration to 0.1 kilogram of beef or horse meat per week. ${ }^{40}$ As a young Jewish Hungarian mother, Mrs. Dévényi noted in her journal after learning about the new food access limitations: “[t]he Jews' food ration is

38 It was decree no. 114.070.1942 of the Ministry of Public Supply [Közellatásügyi Mininisztérium] that from January 1, 1943 introduced food ration cards as the only "currency" for which meat products could be sold. Magyar Husiparosok Lapja, vol. 5, no. 1, January 1943, 1. Find here also the exact numbers for weekly consumption per capita on p. 6, in an article entitled "Értekezlet a husjegyrendszer bevezetéséről" [A meeting about introducing the rationing].

39 Magyar Husiparosok Lapja vol. 5, no. 27, 2 July 1943, 3, a quote from Béla Usety's speech.

40 Decree number 108.500 K.M., entitled "about regulating the food supply of Jews" [a zsidók élelmiszerellátásának szabályozásáról. 
decreasing. We are not allowed to consume milk, eggs or butter. [...] They want to starve us gradually." 41

Once the Sztójay government came into power, it took only a little more than three months to ghettoize and deport to Nazi concentration camps more than 432,000 people from the Hungarian provinces, the vast majority of whom were tragically murdered in Auschwitz-Birkenau. In Budapest, ghettoization was a later and more complicated process than in the countryside. In the capital, a dispersed ghetto was established in June 1944, which in practice meant individual apartment buildings, so-called "Jewish houses" or "Yellow star houses," in which groups of Jewish Hungarians were confined. ${ }^{42}$ Therefore, in the capital city, apartment buildings became the basic units of the ghetto, at least until November, 1944.

Deportations were halted in early July, thus most of the Jews in Budapest at least were not removed outside of the country, but their living conditions were harsh, with only one member per family permitted to leave the "Yellow star house" for the daily food-shopping for a short period of time. In June 1944, this period was first set between 2 p.m. and 5 p.m., which later was changed to 11 a.m. to 5 p.m., but this still meant that by the time the ghetto inhabitants reached the markets, the non-Jews had already purchased much of what was available. ${ }^{43}$ Therefore, a lot depended on alternative sources of food and on how many resources and savings Jewish Hungarians still had.

I want to introduce here the case of Mr. Béla Kling, a butcher from Csányi utca in district VII, who after the war was falsely reported for improper wartime behaviour. As Gideon Hausner, the chief prosecutor of Adolf Eichmann sees it, every trial offers more than just a forum for justice, as it can also set moral examples, it can tell a story, etc. ${ }^{44}$ Butcher Kling could not read Hausner's words, yet he used his denazification procedure for more than just the opposition of a false accusation, but for telling how he had confronted the anti-Jewish campaign. He has showed the ways how he had resisted when Nazi Germans and extreme right nationalists had been piling pressure on Jewish Hungarians in 1944. Kling used invoices issued in April and May, 1944 to prove that he had ordered services from Jewish Hungarian mechanics even after the Nazi

41 Huhák et al., Kismama sárga csillaggal, 44.

42 Cole, Holocaust City, 101-29.

43 Decree numbered 1920/1944.M.E., while on the changes of shopping schedules, see Czingel, Szakácskönyv a túlélésért, 99.

44 See Hausner, Justice in Jerusalem, 76. 
Germans had taken control of Budapest. As late as on 26 May, 1944, while trains filled with Jewish Hungarians were running towards Auschwitz, butcher Kling paid a massive sum, 626 pengős, to a Jewish Hungarian mechanic named Mr. Reichard to repair and maintain his refrigerators. ${ }^{45}$ From another Jewish mechanic Kling ordered the instalment of an electric neon advertisement. ${ }^{46}$ At a time when Jewish Hungarians were already a highly stigmatized group, these were brave acts. This holds true even if we take into consideration the fact that Kling was in a better situation than other butchers. Since he had been selling meat to army units for years, he could more easily afford to make humanitarian gestures than most of his colleagues during the war.

Nevertheless, there were other Budapest butchers who showed solidarity in this period. The butcher shop of Mr. Winter, for example, sold bigger portions of meat to Dr. Dezső Erdész in district VIII even after the governmental decree forbade Jews to purchase meat products. ${ }^{47}$ Another butcher, János Szladovits, had an agreement with the neighbouring shoe-repair shop: for his Jewish Hungarian customers, he always took some of the meat to the shoe-repair shop for the transactions. His Jewish customers were able to enter the business without much risk, since it was not forbidden for Jews to have their shoes fixed. ${ }^{48}$ After leaving the money, the customers quickly walked back to their "Yellow star house" with the food they had purchased. This method demonstrates that if a butcher wanted to sell meat products to Jewish Hungarians, he was able to circumvent anti-Jewish decrees and regulations concerning food rations. Another way was to deliver meat directly to the ghetto house, as Vilmos Szabó did. Szabó and his wife took turns delivering food to their client, Mrs. Engel, in Wesselényi utca. ${ }^{49}$

On 15 October, 1944, Horthy attempted to withdraw from the Axis alliance, however this attempt was aborted shortly after the radio announcement of his plan. The Regent was held by the Gestapo, and on the next day the extreme right Arrow Cross movement's leader, Ferenc Szálasi formed a government with the support of the occupying Nazi German forces. Shortly after this, Adolf Eichmann arrived in Hungary and requested the "loaning" of 50,000 able-bodied Jewish Hungarians from Budapest to the Third Reich. Jewish Hungarians were

45 HU BFL XVII. 1597, box no 3, the case of Béla ifj. Kling. See the invoice issued by László Reichard on 26 May, 1944.

46 Ibid., see the invoice issued by Mr. Unterberger.

47 HU BFL XVII. 1597, box no. 6, find this episode in the case of Mrs. Jenő Winter from Lujza utca 2.

48 HU BFL XVII. 1597, box no. 5, the case of János Szladovits from Róbert Károly krt. 34-36.

49 HU BFL XVII. 1597, box no. 5, the case of Vilmos Szabó, see the statements of Mrs. Engel, Mr. Blau, and Mrs. Klein. 
then soon moved from the "Yellow star houses." Those who had protective papers like the ones issued by Raoul Wallenberg, could settle in the buildings of the so-called international ghetto, whereas the majority was moved to the "main ghetto," which was set up in district VII, around Klauzál Square.

The changes in the Hungarian political leadership provoked changes at the top of the Budapest butcher's hierarchy as well. A certain Mr. Gruber became the head of the professional chamber, and he created a new list of the Arrow Cross-affiliated butchers. It was this list of people who from now on were to receive proper supplies of meat. ${ }^{50}$ Since the popular market hall on Klauzál Square became part of the newly established main ghetto, non-Jewish meat sellers originally located there started to request new butcher shops from $\mathrm{Mr}$. Gruber. The aim was to relocate outside of the ghetto to those several empty business premises that had been confiscated from Jews. Among those requesting new shops was Mrs. Czakó, who was remembered as having publicly shown her husband's Arrow Cross party membership card to the new leader, Mr. Gruber. ${ }^{51}$ It is interesting from a gender point of view how Mrs. Czakó, whose husband had been recalled by the army took the initiative within this patriarchal society and went to the head of this male-dominated professional cluster to present her requests in the late autumn of 1944.

However, it is even more interesting how butchers and other ordinary tradesmen intended to profit from the anti-Jewish rules and get themselves better shops, positions, etc. at the expense of the excluded Jews. Again, we have some positive examples, like the aforementioned butcher Kling. Several survivors of the Holocaust spoke about how, during their time in the closed ghetto (December 1944-January 1945), Mr. Béla Kling had brought them meat, animal fat, etc., which meant putting his own liberty and life at risk. ${ }^{52}$ Elsewhere, the non-Jewish Pál Tóth, who normally ran a butcher business at the Garay market hall, survived the Soviet siege of Budapest in a building, where Jewish Hungarians lived under the protection of the Swedish embassy. He took meat to the building and even cooked it and offered it to the ghettoized people. ${ }^{53}$

\footnotetext{
50 HU BFL XVII. 1597, See for example the case of Antal Schwalm on this.

51 HU BFL XVII. 1597, box no. 1, the case of Balázs Czakó, see the testimony of Lenke Illyefalvi on 9 June, 1945.

52 HU BFL XVII. 1597, the case of Béla ifj. Kling, box no 3. Find the declaration of the former inhabitants of Nagyatádi Szabó / Kertész utca 35, dated 28 March, 1945.

53 HU BFL XVII. 1597, box no. 5, the case of Pál Tóth, Kárpát utca 3.
} 


\section{Conclusion}

These last examples prove that for many everyday Hungarian tradesmen, such as the Budapest butchers, there were some options available to help their Jewish neighbours' survival. When helping, butcher Kling was potentially saving his customers' lives, and thus his acts could be seen as having been motivated by personal interest. Still, the manner in which he maintained his business relations with Jewish handymen after the German invasion of the city suggests that he simply cared about others. Because Kling hired these Jewish men, they were able to earn money at a time when their own government was already limiting their space of existence and their opportunities. For some of them, at times, the signs of humanity could have meant more than the actual economic reward.

However, the real value of these micro historical cases is not in their representativeness, but in the "additional information generated by analysis conducted on the microscale." "In fact, the role of micro history is to describe how individuals or small groups manoeuvre within a normative social set-up: their actions and decisions tell a lot about the cracks and the contradictions of the given social system. They also give us an idea of the extent of freedom in which these individuals could make their choices. ${ }^{55}$

Reading these archival sources results in the impression that generally in 1942-43, there were very strong intentions within the butchers' trade to make it impossible for the Jewish butchers to continue to pursue their trade. The deep professional crisis with which the Budapest meat industry was confronted during the Second World War certainly played a part in this, but targeting systematically the Jewish Hungarian colleagues, nevertheless, suggests that anti-Jewish sentiments were widely shared within this professional cluster. The tendentious pro-extreme right preference at the slaughterhouses clearly had been influential in reinforcing these trends in the micro world of the Budapest butchers, but other, more macro factors were important as well.

One such factor was, for instance, the changes in social respectability, which led to a change as early as 1939-1940 in the leadership of the butchers' professional chamber. Thus, the anti-Jewish tendencies in the history of the Budapest butchers could be explained partly by the group's aim to maintain social respectability in a society in which Jews were stigmatized, partly by

54 Zalc and Bruttmann, Microbistories of the Holocaust, 4.

55 Levi, "On Microhistory", 93-95. 
the internalized anti-Jewish prejudice, but as a third explanation, self-interest undoubtedly played a crucial role here as well. Governmental meddling into the affairs of the meat industry through food rationing, efforts to stock up on meat, and regulations concerning the number of slaughtering activities, etc., made things even worse.

However, butchers like János Szladovits, Mr. Winter, and Mr. Kling demonstrated that it was always possible to bend the rules and provide meat for Jewish clients, even after the Hungarian government had made this a rather difficult task to achieve. Finally, it is worth mentioning that the denazification check interestingly took over some functions of the "master's exam," as through this process it was possible to control the re-entry into the profession of butchers after the war. Consequently, this denazification check provided an excellent opportunity not only for retribution, but also for the vengeance of wartime insults. In the end, approximately 93 percent of the Budapest butchers got the green light to continue practicing their profession following the denazifying check, while some 7 percent of them were either banned or suffered even harsher punishments. ${ }^{56}$ One example of the latter group was $\mathrm{Mr}$. Károly Jánossy, who had a butcher shop at Népszínház utca 27 in district VIII. Although his wife had requested his denazification following the war in March 1945, this request was rejected due to an ongoing investigation of the People's Court. ${ }^{57}$ The investigation established that Jánossy had treated Jewish Hungarian forced labourers cruelly during the war by beating them, and even causing fatal injuries to some of them, while also calling them "stinky Jews". ${ }^{58}$ This Budapest butcher was sentenced to death in June 1946 and was executed as a war criminal on 17 February, 1947..$^{9}$

56 HU BFL XVII. 1597, box no. 6, a complaint letter of a Communist Party official.

57 HU BFL XXV.1.a-1945-2185 the case of Máté Kele and other defendants.

58 Ibid., a sentence numbered Nb.VI.2185/1945, dated 25 June, 1946.

59 The research to this article was partially sponsored by the Central European University Foundation of Budapest. The theses explained herein are representing the own ideas of the author, but not necessarily reflect the opinion of Central European University Foundation of Budapest / Közép-európai Egyetem Institute for Advanced Study. 


\section{Bibliography}

Primary sources

Budapest Főváros Levéltára [Budapest City Archives] (BFL)

XVII. 1597. A Budapesti Mészárosok és Hentesek Ipartestületének Igazolóbizottsága Iratai [Files of the Justificatory Committee of the Budapest Butchers' and Slaughter-men' Chamber], 1945-46.

XVII. 1598. A Magyar Házfelügyelők és Segéd-házfelügyelők 291/a. sz. Igazoló Bizottságának iratai [Files of Justificatory Committee no. 291/a of the Hungarian Concierges and Assistant Concierges], 1945-47.

XXV. 1.a 1945/2185 Kele Máté és Társai Büntetőpere [The criminal court case of Máté Kele and other defendants].

Magyar Husiparosok Lapja [The periodical of Hungarian meat industry workers], 1942-43, volumes 4-5.

Secondary sources

Barna, Ildikó, and Andrea Pető. Political Justice in Budapest after World War II. Budapest: Central European University, 2015.

Cole, Tim. Holocaust City: The Making of a Jewish Ghetto. New York: Routledge, 2003.

Czingel, Szilvia. Szakácskönyv a túlélésért [Cookbook for survival]. Budapest: Corvina, 2013.

Goffman, Erving. Stigma: Notes on the Management of Spoiled Identity. New York: Jason Aronson, 1974.

Hadas, Miklós, and Gyula Zeke. Egy fölösleges ember élete: beszélgetések Vázsonyi Vilmossal [The life of an unnecessary man: conversations with Vilmos Vázsonyi]. Budapest: Balassi, 2012.

Hausner, Gideon. Justice in Jerusalem. New York: Harper and Row, 1966.

Huhák, Heléna, András Szécsényi, and Erika Szívós, eds. Kismama sárga csillaggal: Egy fiatalasszony naplója a német megszállástól 1945 júliusáig [Mother-to-be with yellow star: Diary of a young woman from the German occupation to July 1945]. Budapest: Jaffa, 2015.

Jarausch, Konrad H. Broken Lives: How Ordinary Germans Experienced the Twentieth Century. Princeton and Oxford: Princeton University Press, 2018.

Levi, Giovanni. "On Microhistory." In New Perspectives in Historical Writing, edited by Peter Burke, 93-114. Cambridge: Polity Press, 1991.

Margittai, Linda. "Zsidókérdés a Délvidéken" [Jewish question in Lower Hungary]. PhD Diss., University of Szeged, 2019. 
Markó, Géza. "Marok" kereskedōk és iparosok sqaknévsora ["Marok" yellow pages]. Budapest: Held, 1941.

Mosse, George L. Confronting History: A Memoir. Madison: University of Wisconsin, 2000.

Stone, Dan. Goodbye to all that? The story of Europe since 1945. Oxford: Oxford University Press, 2014.

Zalc, Claire, and Tal Bruttmann, eds. Microhistories of the Holocaust. New York: Berghahn, 2016. 